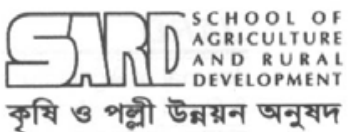

\title{
Costs and Earnings of Fishing Efforts of Marine Set-Bag-Net (MSBN) Fisheries of Bangladesh
}

\author{
M. J. RAHMAN ${ }^{*}$, M. ZAHER ${ }^{2}$ AND A.K.Y. HAROON ${ }^{3}$ \\ ${ }^{1 \& 3}$ Bangladesh Fisheries Research Institute, Marine Fisheries \& Technology Station, \\ Cox's Bazar-4700, Bangladesh \\ ${ }^{2}$ Bangladesh Fisheries Research Institute, Freshwater Station, Mymensingh-2201, Bangladesh
}

Set-bag-net is one of the most important commercial fishing gears in the artisanal marine fisheries of Bangladesh. There are two types of set-bag-nets, namely, estuarine set-bag-net (ESBN) and marine set-bag-net (MSBN) (Mazid and Rahman 2005). The gear is non-selective to size and species and catches juveniles, youngs and adults (Islam et al. 1993, BOBP 1993, MFTS 2004, Mazid and Rahman 2005). The MSBN (locally called, sagor behundi) fishery is relatively resource friendly compared to the ESBN fishery as the fishing activities mainly take place in the offshore marine environment and the mesh size in the cod end is comparatively larger than that of ESBN (Mazid and Rahman 2005). According to the BOBP (1993), MSBN contributes about $27 \%$ of the total set bag-net production. However, very little work have so far been done on the MSBN, especially on the cost and earnings of the fishery, except some preliminary works on catch rate and catch composition (Quayum et al. 1993, Islam et al. 1993, BOBP 1993, and 1994, Mazid and Rahman 2005). Detailed studies on the costs and earnings from the fishery and basic socioeconomic of the fishers are very important for the formulation of conservation and sustainable community based management of the marine fisheries resources. To overcome the shortfalls of the information about the costs and earnings of the fishery and basic socioeconomic of the fishers the present investigation was undertaken.

The article includes some preliminary but valuable information about the costs of manufacturing and repairing of crafts and gears of MSBN fishery and some basic socioeconomic aspects of MSBN fishers in Bnagladesh.

All important MSBN operating areas in Bangladesh viz: Cox's Bazar Sadar, Moheshkhali and Kutubdia of Cox's Bazar, Khepupara of Patuakhali and Dublarchar of Khulna districts were included in the study. An approximate cost of manufacturing and repairing of MSBN crafts including the costs of materials, costs of manufacturing, costs of engine, costs of annual repairing, etc. were estimated separately for each of the sampling areas (Table I). The information was collected after interviewing at least $40 \mathrm{MSBN}$ owners in each of the five sampling stations.

The average costs of manufacturing and repairing of the MSBN crafts were found to be Tk. 5,60,000/- and Tk. 29,000/- per annum (Tk. 70/= equals to 1 US\$), respectively (Table I). The costs of manufacturing and repairing of MSBN crafts were found to be the lowest (Tk. 3,95,000/-) in Dublarchar and the highest (Tk. 6,90,000/-) in Kutubdia (Table I). The main reason might be the cheaper wooden materials in the Sunderban region. Another factor might be the cheaper labour in the Dublarchar areas (Khulna region) than that of in other regions.

\footnotetext{
* Corresponding author: BFRI, Marine Fisheries \& Technology Station, Cox's Bazar, Mobile: 01711408339 , E-mail: jrhmn@yahoo.com

(C) 2006 School of Agriculture and Rural Development, Bangladesh Open University, All rights reserved.
} 
Table I. Costs of manufacturing and repairing of crafts of marine set-bag-net (MSBN) fishery during 2003-04 fishing season in different areas of Bangladesh.

\begin{tabular}{lcccccc}
\hline $\begin{array}{l}\text { Sampling } \\
\text { areas }\end{array}$ & $\begin{array}{c}\text { Costs of } \\
\text { materials } \\
\text { (Tk.*) }\end{array}$ & $\begin{array}{c}\text { Costs of } \\
\text { manufacturing } \\
\text { (Tk.) }\end{array}$ & $\begin{array}{c}\text { Costs of } \\
\text { engine } \\
\text { (Tk.) }\end{array}$ & $\begin{array}{c}\text { Total } \\
\text { costs } \\
\text { (Tk.) }\end{array}$ & $\begin{array}{c}\text { Costs of } \\
\text { annual } \\
\text { repairing } \\
\text { (Tk.) }\end{array}$ & $\begin{array}{c}\text { Longevity } \\
\text { (Year) }\end{array}$ \\
\hline \hline $\begin{array}{l}\text { Moheshkhali, } \\
\text { Cox's Bazar }\end{array}$ & $3,50,000$ & 78,000 & $2,20,000$ & $6,48,000$ & 30,000 & 15 \\
$\begin{array}{l}\text { Kutubdia, } \\
\text { Cox's Bazar }\end{array}$ & $4,00,000$ & 80,000 & $2,10,000$ & $6,90,000$ & 40000 & 16 \\
$\begin{array}{l}\text { Cox's Bazar } \\
\begin{array}{l}\text { Sadar } \\
\text { Khepupara, }\end{array}\end{array}$ & $3,50,000$ & 75,000 & $2,20,000$ & $6,45,000$ & 35,000 & 18 \\
$\begin{array}{l}\text { Patuakhali } \\
\begin{array}{l}\text { Dublarchar, } \\
\text { Khulna }\end{array}\end{array}$ & $1,80,000$ & 60,000 & $1,80,000$ & $4,20,000$ & 20,000 & 14 \\
\hline Average & $1,40,000$ & 65,000 & $1,90,000$ & $3,95,000$ & 20,000 & 12 \\
\hline
\end{tabular}

*(Tk. $70 /=$ equals to 1 US $\$)$

Approximate cost of manufacturing and repairing of the gear of the MSBN fishery including the costs of materials, costs of manufacturing, costs of annual repairing, etc. were also estimated separately for each of the sampling areas. The average costs of manufacturing and repairing of the gear were Tk. 35,300/- and Tk. 2,900/- per annum, respectively (Table II). The costs of the gears (MSBN) were found to be lowest (Tk. 22,000/-) in Khepupara and the highest (Tk.45,000/-) in Cox's Bazar (Table II). The main reason might be the size of the gear, being smaller in Khepupara and larger in Cox's Bazar. Smaller nets need fewer materials than that of larger nets. Other factor might be the cheaper labour in Khepupara region than that of in Cox's Bazar region.

Table II. Costs of manufacturing and repairing of gears of marine set-bag-net (MSBN) fishery during 2003-04 fishing season in different areas of Bangladesh.

\begin{tabular}{lccccc}
\hline $\begin{array}{l}\text { Sampling } \\
\text { areas }\end{array}$ & $\begin{array}{c}\text { Costs of } \\
\text { materials } \\
\text { (Tk.*) }\end{array}$ & $\begin{array}{c}\text { Costs of } \\
\text { manufacturing } \\
\text { (Tk.) }\end{array}$ & $\begin{array}{c}\text { Total costs } \\
\text { (Tk.) }\end{array}$ & $\begin{array}{c}\text { Costs of annual } \\
\text { repairing } \\
\text { (Tk.) }\end{array}$ & $\begin{array}{c}\text { Longevity } \\
\text { (Year) }\end{array}$ \\
\hline \hline $\begin{array}{l}\text { Moheshkhali, } \\
\text { Cox's Bazar }\end{array}$ & 35,000 & 7,500 & 42,500 & 3,500 & 5 \\
$\begin{array}{l}\text { Kutubdia, Cox's } \\
\text { Bazar }\end{array}$ & 35,000 & 8,000 & 43,000 & 3,000 & 5 \\
$\begin{array}{l}\text { Cox's Bazar } \\
\begin{array}{l}\text { Sadar } \\
\text { Khepupara, }\end{array}\end{array}$ & 35,000 & 10,000 & 45,000 & 4,000 & 6 \\
$\begin{array}{l}\text { Patuakhali } \\
\text { uublarchar, }\end{array}$ & 15,000 & 7,000 & 22,000 & 2,000 & 5 \\
Khulna & 18,000 & 6,000 & 24,000 & 2,000 & 4 \\
\hline Average & $\mathbf{2 7 , 6 0 0}$ & $\mathbf{7 , 7 0 0}$ & $\mathbf{3 5 , 3 0 0}$ & $\mathbf{2 , 9 0 0}$ & $\mathbf{5}$ \\
\hline
\end{tabular}

*(Tk. $70 /=$ equals to 1 US $\$)$

Some basic socioeconomic information were collected by interviewing more than 50 fishers in each of the sampling areas of Cox's Bazar region to get some basic ideas about the MSBN fishers. The information included the income from fishing as well as from other sources, number of dependant, educational status of the fishers and their families, annual savings, etc. Generally, five different categories of fishers were present in the MSBN fishery viz. owner, skipper, driver, crews 
and cook. The socioeconomic information were collected for each of the categories and summarized (Table III).

Table III. Some basic socioeconomic information of marine set-bag-net (MSBN) fishers during 2003-04 fishing season in Cox's Bazar areas of Bangladesh.

\begin{tabular}{|c|c|c|c|c|c|c|}
\hline $\begin{array}{l}\text { Category } \\
\text { of fishers }\end{array}$ & $\begin{array}{c}\text { Income from } \\
\text { fishing } \\
\text { (Tk.*) }^{*} \\
\end{array}$ & $\begin{array}{l}\text { Other source } \\
\text { (Tk.) }\end{array}$ & $\begin{array}{l}\text { Number of } \\
\text { Dependent }\end{array}$ & $\begin{array}{l}\text { Education } \\
\text { level (Own) }\end{array}$ &  & $\begin{array}{c}\text { Annual } \\
\text { savings } \\
\text { (Tk.) } \\
\end{array}$ \\
\hline Owner & $\begin{array}{c}2,00,000- \\
4,00,000\end{array}$ & $\begin{array}{l}1,00,000- \\
2,00,000\end{array}$ & $5-10$ & $\begin{array}{l}\text { Primary- } \\
\text { High School }\end{array}$ & $\begin{array}{l}\text { Primary-High } \\
\text { School }\end{array}$ & $\begin{array}{c}1,00,000- \\
2,00,000\end{array}$ \\
\hline Skipper & $\begin{array}{l}40,000- \\
1,30,000\end{array}$ & $\begin{array}{l}5,000- \\
50,000\end{array}$ & $5-6$ & $\begin{array}{l}\text { Illiterate- } \\
\text { Primary }\end{array}$ & $\begin{array}{l}\text { Illiterate-High } \\
\text { School }\end{array}$ & $\begin{array}{c}10,000- \\
50,000\end{array}$ \\
\hline Driver & $\begin{array}{l}20,000- \\
50,000\end{array}$ & $\begin{array}{l}5,000- \\
30,000\end{array}$ & $4-7$ & $\begin{array}{l}\text { Illiterate- } \\
\text { Primary }\end{array}$ & $\begin{array}{l}\text { Illiterate-High } \\
\text { School }\end{array}$ & $\begin{array}{l}5,000- \\
30,000\end{array}$ \\
\hline Labourer & $\begin{array}{l}15,000- \\
25,000\end{array}$ & $\begin{array}{l}1,000- \\
5,000\end{array}$ & $3-8$ & $\begin{array}{l}\text { Illiterate- } \\
\text { Primary }\end{array}$ & $\begin{array}{l}\text { Illiterate-High } \\
\text { School }\end{array}$ & - \\
\hline Cook & $\begin{array}{l}15,000- \\
20,000\end{array}$ & $\begin{array}{l}1,000- \\
5,000\end{array}$ & 3-8 & $\begin{array}{l}\text { Illiterate- } \\
\text { Primary }\end{array}$ & $\begin{array}{l}\text { Illiterate-High } \\
\text { School }\end{array}$ & - \\
\hline
\end{tabular}

*(Tk. $70 /=$ equals to 1 US\$)

The family size varied from three to 10 members. The educational background was not found encouraging. Most of the fishers were illiterate or educated up to primary level. However, educational levels were comparatively better for their dependants, which indicate better future for the next generation of the fishers (Table III). Most of the fishers earn more than $90 \%$ of their income from fishing (Table III). Annual income of boat owners was about Tk. 0.2-0.4 million and the skipper also earned a moderate amount (Table III). The annual savings for the owners and skippers were also moderate. However, the income of other fishers varied from Tk.15,000/- to Tk. $50,000 /$ - and they had very little amount for savings (Table III).

\section{LITERATURE CITED}

BOBP (Bay of Bengal Programme). 1993. Socioeconomic conditions of the estuarine set-bag-net fisher folk in Bangladesh. BOBP/W/90. $32 \mathrm{pp}$.

BOBP (Bay of Bengal Program). 1994. Biosocioeconomic assessment of the effect of the estuarine set-bag-net on the marine fisheries of Bangladesh. BOBP/WP/94. $28 \mathrm{pp}$.

Islam, M. S., Khan, M. G., Quayum, S. A., Sada, M. N. and Chowdhury, Z. A. 1993. The estuarine set- bag-net fishery. In "Studies of interactive marine fisheries of Bangladesh". pp. 19-50. Bay of Bengal Programme, Madras, India.

Mazid, M. A. and Rahman, M. J. 2005. Studies on the impacts of marine set-bag-net (MSBN) on the marine fisheries resources of Bangladesh. Final Report, Bangladesh Fisheries Research Institute, Marine Fisheries \& Technology Station, Cox's Bazar. 88 pp.

MFTS (Marine Fisheries \& Technology Station). 2004. Studies on the impacts of marine set-bag-net (MSBN) on the marine fisheries resources of Bangladesh. Third Quarterly Report, Bangladesh Fisheries Research Institute, Marine Fisheries \& Technology Station, Cox's Bazar. 17 pp.

Quayum, S. A., Khan, M. G., Islam, M. S., Sada, M. N. and Chowdhury, Z. A. 1993. The marine set bag-net fishery. In "Studies of interactive marine fisheries of Bangladesh". pp. 65-78. Bay of Bengal Programme, Madras, India. 